Prepared in cooperation with the Trinity River Restoration Project

\title{
Geomorphic Mapping to Support River Restoration on the Trinity River Downstream from Lewiston Dam, California, 1980-2011
}
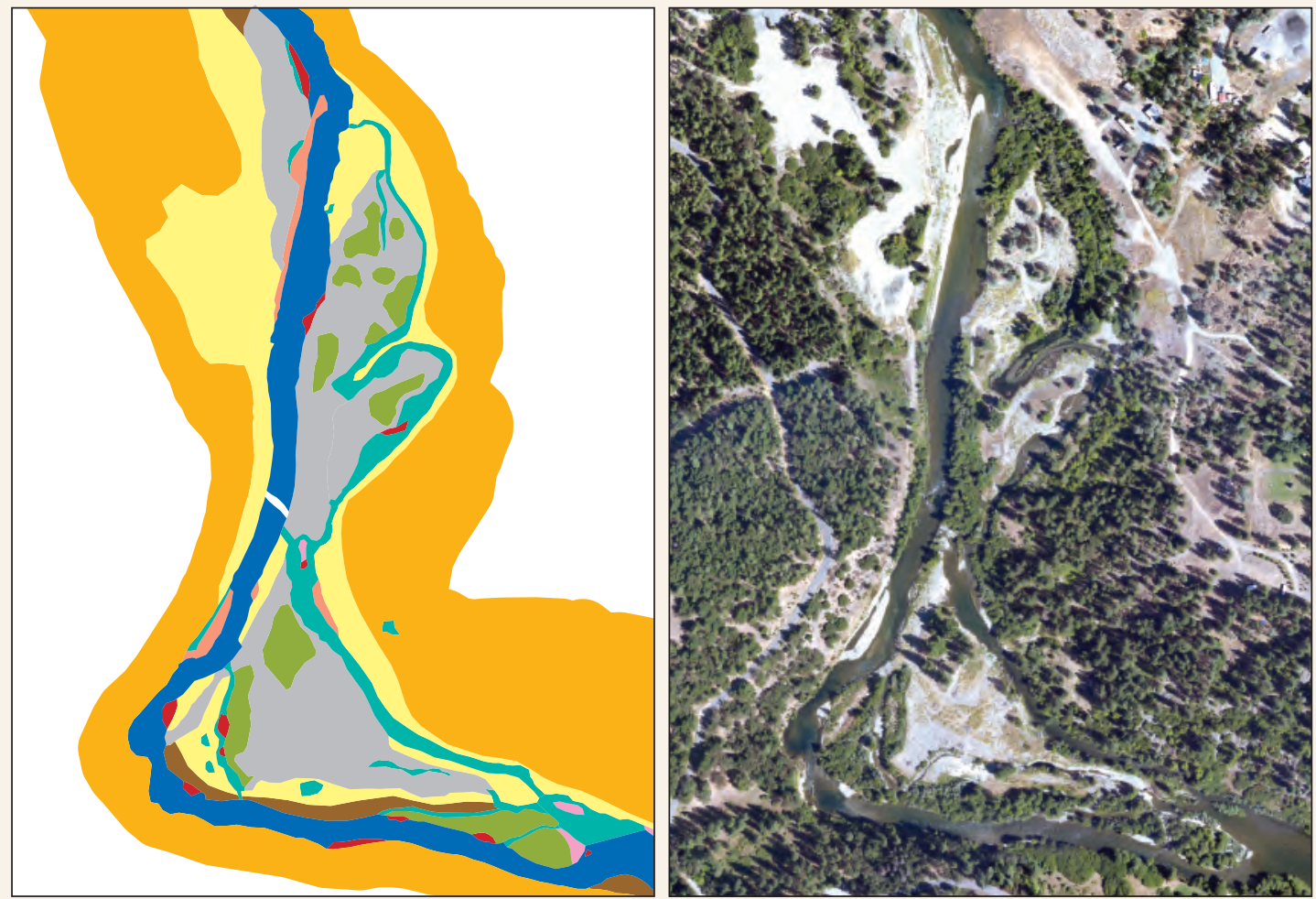

Geomorphic features along the Trinity River, California, downstream from Lewiston Dam, 2011
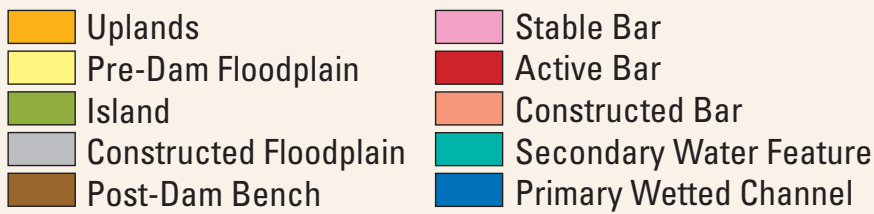

\section{Open File Report 2015-1047}





\section{Geomorphic Mapping to Support River Restoration on the Trinity River Downstream from Lewiston Dam, California, 1980-2011}

By Jennifer A. Curtis and Timothy M. Guerrero

Prepared in cooperation with the Trinity River Restoration Program

Open-File Report 2015-1047 


\title{
U.S. Department of the Interior SALLY JEWELL, Secretary
}

\section{U.S. Geological Survey Suzette M. Kimball, Acting Director}

\author{
U.S. Geological Survey, Reston, Virginia: 2015
}

For more information on the USGS - the Federal source for science about the Earth, its natural and living resources, natural hazards, and the environment—visit http://www.usgs.gov or call 1-888-ASK-USGS.

For an overview of USGS information products, including maps, imagery, and publications, visit http://www.usgs.gov/pubprod/.

Any use of trade, firm, or product names is for descriptive purposes only and does not imply endorsement by the U.S. Government.

Although this information product, for the most part, is in the public domain, it also may contain copyrighted materials as noted in the text. Permission to reproduce copyrighted items must be secured from the copyright owner.

Suggested citation:

Curtis, J.A., and Guerrero, T.M., 2015, Geomorphic mapping to support river restoration on the Trinity River downstream from Lewiston Dam, California, 1980-2011: U.S. Geological Survey Open-File Report 2015-1047, 15 p., http://dx.doi.org/10.3133/ofr20151047.

Suggested citation for Data related to this OFR:

Curtis, J.A., and Guerrero, T.M., 2015, Database of Geomorphic Features, Trinity River, California, 1980-2011: U.S.

Geological Survey Data Release http://dx.doi.org/10.5066/F7TT4P04.

ISSN 2331-1258 (online) 


\section{Contents}

Abstract
Introduction.
Purpose and Scope
Study Area
Geomorphic Mapping Geodatabase
Mapping Protocol
Terrestrial Features
Centerlines

\section{Figures}

1. Map showing study area location along the Trinity River, California, downstream from Lewiston Dam

2. Map showing study area along the Trinity River, California, extending from Lewiston Dam to the confluence of the North Fork Trinity River.

3. Diagram showing hierarchy of geomorphic mapping features with an explanation of the size and frequency of inundation by peak-flow releases from Lewiston Dam in California...

4. Photo showing example of the topographic relation among depositional and constructed features on the Upper Trinity River, California, downstream from Lewiston Dam

5. Maps showing base photo imagery and geomorphic features in 1980, 2001, and 2011 at an example location near the Reading Creek Rehabilitation Site on the Trinity River, California, downstream from Lewiston Dam...

6. Maps showing base photo imagery and examples of bar vegetation and stability class in 1980, 2001, and 2011 at example locations along the Trinity River, California, downstream from Lewiston Dam: $A$, downstream of Rush Creek confluence, and $B$, between the Indian Creek and Weaver Creek confluences.

7. Maps showing examples of secondary-water features in 1980, 2001, and 2011 for selected locations along the Trinity River, California, downstream from Lewiston Dam

8. Maps showing examples of the pre-dam floodplain, constructed floodplains, and post-dam topographic benches in 1980, 2001, and 2011 along the Trinity River, California, downstream from Lewiston Dam: $A$, the Sawmill Rehabilitation Site and $B$, the Reading Creek Rehabilitation Site 


\section{Tables}

1. Ortho-rectified photography and acquisition dates $(1960,1965,1975,1980,1997$, $2001,2006,2009,2011)$ for base imagery used to produce six geomorphic maps of the study area along the Trinity River, California, downstream from Lewiston Dam ........4

2. Coded values representing categorical differences among river features for the geodatabase entitled "Trinity River California Geomorphic Maps 1980-2011."

\section{Conversion Factors}

[Inch/pound to International System of Units]

\begin{tabular}{lcc}
\hline Multiply & By & To obtain \\
\hline foot $(\mathrm{ft})$ & Length & meter $(\mathrm{m})$ \\
\hline & 0.3048 & \\
\hline cubic foot per second $\left(\mathrm{ft}^{3} / \mathrm{s}\right)$ & Flow rate & cubic meter per second $\left(\mathrm{m}^{3} / \mathrm{s}\right)$ \\
\hline
\end{tabular}

[International System of Units to Inch/pound]

\begin{tabular}{lll}
\hline \multicolumn{1}{c}{ Multiply } & By & To obtain \\
\hline millimeter $(\mathrm{mm})$ & Length & \\
meter $(\mathrm{m})$ & 0.03937 & inch (in.) \\
kilometer $(\mathrm{km})$ & 3.281 & foot (ft) \\
\hline & 0.6214 & mile (mi) \\
\hline square meter $\left(\mathrm{m}^{2}\right)$ & Area & square foot $\left(\mathrm{ft}^{2}\right)$ \\
\hline
\end{tabular}

\section{Datums}

Vertical coordinate information is referenced to the North American Vertical Datum of 1988 (NAVD 88).

Horizontal coordinate information is referenced to the North American Datum of 1983 (NAD 83).

Elevation, as used in this report, refers to distance above the vertical datum.

\section{Abbreviations and Acronyms}

$\begin{array}{ll}\text { RMSE } & \text { root mean square error } \\ \text { ROD } & \text { Record of Decision } \\ \text { TRRP } & \text { Trinity River Restoration Program } \\ \text { USFWS } & \text { U.S. Fish and Wildlife Service }\end{array}$




\title{
Geomorphic Mapping to Support River Restoration on the Trinity River Downstream from Lewiston Dam, California, 1980-2011
}

\author{
By Jennifer A. Curtis and Timothy M. Guerrero
}

\begin{abstract}
Historic land use, dam construction, water storage, and flow diversions in the Trinity River watershed have resulted in downstream geomorphic change, loss of salmonid habitat, and declines in salmonid populations. The USGS in cooperation with the Trinity River Restoration Program, a multi-agency partnership tasked with implementing federally mandated restoration, completed a geomorphic change assessment to inform the planning process for future restoration work. This report documents an ARCMAP geodatabase (v.10.0) containing geomorphic features digitized from a series of rectified orthophotographs (http://dx.doi.org/10.5066/ F7TT4P04). Upland, riparian, and channel features were digitized from six available base images $(1980,1997,2001$, 2006, 2009, and 2011). This report describes the structure of the geodatabase and the methods used to delineate individual geomorphic features.
\end{abstract}

\section{Introduction}

Completion of the Trinity River Diversion in 1964 enabled transfer of 75 to 90 percent of the average annual inflow into Trinity Lake (fig. 1) from the upper Trinity River to the upper Sacramento River for power generation, agricultural, and other out-of-basin uses (U.S. Fish and Wildlife Service, 1980). Subsequent declines in salmon and steelhead populations led to a series of environmental studies that culminated in the Trinity River Flow Evaluation Study (U.S. Fish and Wildlife Service and Hoopa Valley Tribe, 1999), the Record of Decision (U.S. Department of the Interior, 2000), and the organization of a multi-agency Trinity River Restoration Program (TRRP; http://www.trrp.net). The Record of Decision (ROD) authorized management actions to restore salmon and steelhead populations in the reach downstream from Lewiston Dam to pre-dam levels.

The TRRP is responsible for implementing ROD-mandated restoration actions that included mechanical restoration, mainstem sediment management, watershed rehabilitation, and improved streamflow conditions. In 2001, the TRRP began restoration designed to create and maintain salmonid habitat in the 65-kilometer $(\mathrm{km})$ management reach downstream from Lewiston Dam. Initially, the mandatedflow releases were not fully implemented. Beginning in water year 2005, the annual flow diversion was decreased to 52-75 percent of the average annual inflow into Trinity Lake. The USGS, in cooperation with the TRRP, produced a series of digital geomorphic maps and, in a companion report (Curtis and others, 2015), assessed geomorphic changes during the pre-ROD (1980-2000) and the post-ROD (2001-11) periods. The geomorphic feature data documented in this report can be used to assess and improve the TRRP's adaptive management program and restoration planning process.

\section{Purpose and Scope}

This report describes a geodatabase that contains geomorphic feature data used by the USGS to quantify system-wide geomorphic change within a $65-\mathrm{km}$ restoration reach along the mainstem Trinity River downstream from Lewiston Dam, California. These data built upon previous mapping efforts at the site and reach scale (Gallagher, 1995; McBain and Trush, Inc., 1997; U.S. Fish and Wildlife Service and Hoopa Valley Tribe, 1999; Trinity River Restoration Program, 2005, Gaeuman, 2009; May and others, 2009; Trinity River Restoration Program and ESSA, Ltd., 2009; Hoopa Valley Tribe and others, 2011a; Hoopa Valley Tribe and others, 2011b). The uncertainty associated with the digitized geomorphic feature data was assessed by quantifying operational errors, differences in the exposure of channel units due to variable streamflows during sequential photo acquisition, and digitizing errors due to rectification of the base imagery and feature obscurity related to vegetation or shadows. Although the mapping data are presented in metric units, we used English units to characterize flow data (cubic feet per second, $\mathrm{ft}^{3} / \mathrm{s}$ ) because they are commonly used in the Trinity River management community. 


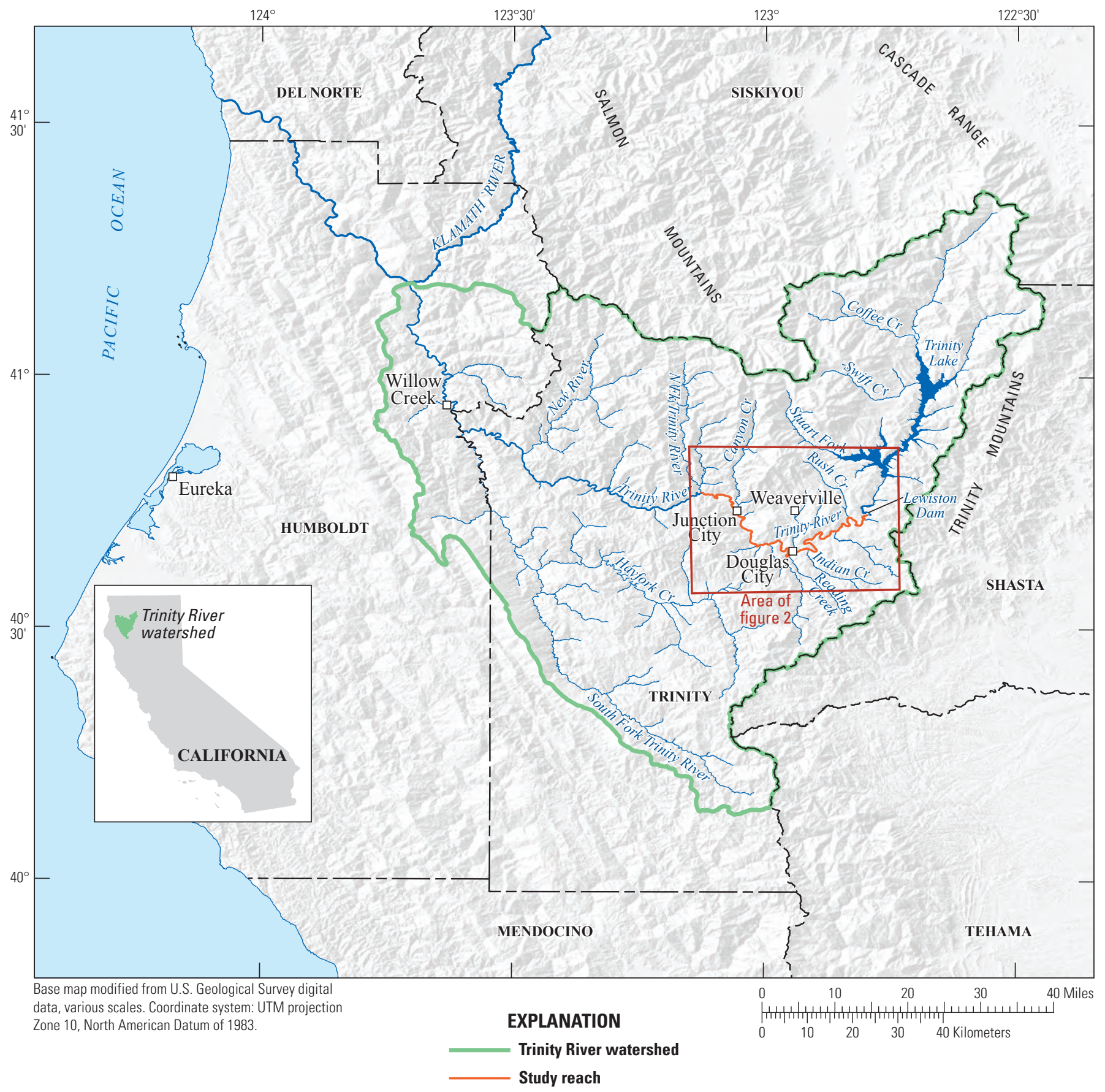

Figure 1. Study area location along the Trinity River, California, downstream from Lewiston Dam.

\section{Study Area}

The Trinity River, in northwestern California (fig. 1) is the largest tributary to the Klamath River and flows through the Klamath Mountain geologic province (Irwin, 1966; Irwin, 1994). The study area included a $65-\mathrm{km}$ restoration reach along the upper mainstem Trinity River that extends from Lewiston Dam downstream to the confluence with the North Fork Trinity River (fig. 2). Historic land use, dam construction, water storage, and flow diversions in the Trinity
River watershed caused downstream geomorphic changes that simplified the channel morphology and resulted in the loss of salmonid habitat and population declines (U.S. Fish and Wildlife Service and Hoopa Valley Tribe, 1999). Restoration efforts from 1970 to present have included construction of artificial spawning beds and side channels, riparian berm removal and re-contouring of channel margins (locally referred to as feathered edges), pool dredging, managed-flow releases, bridge replacement, large-scale bank-rehabilitation projects, gravel augmentation, and installation of engineered log jams. 


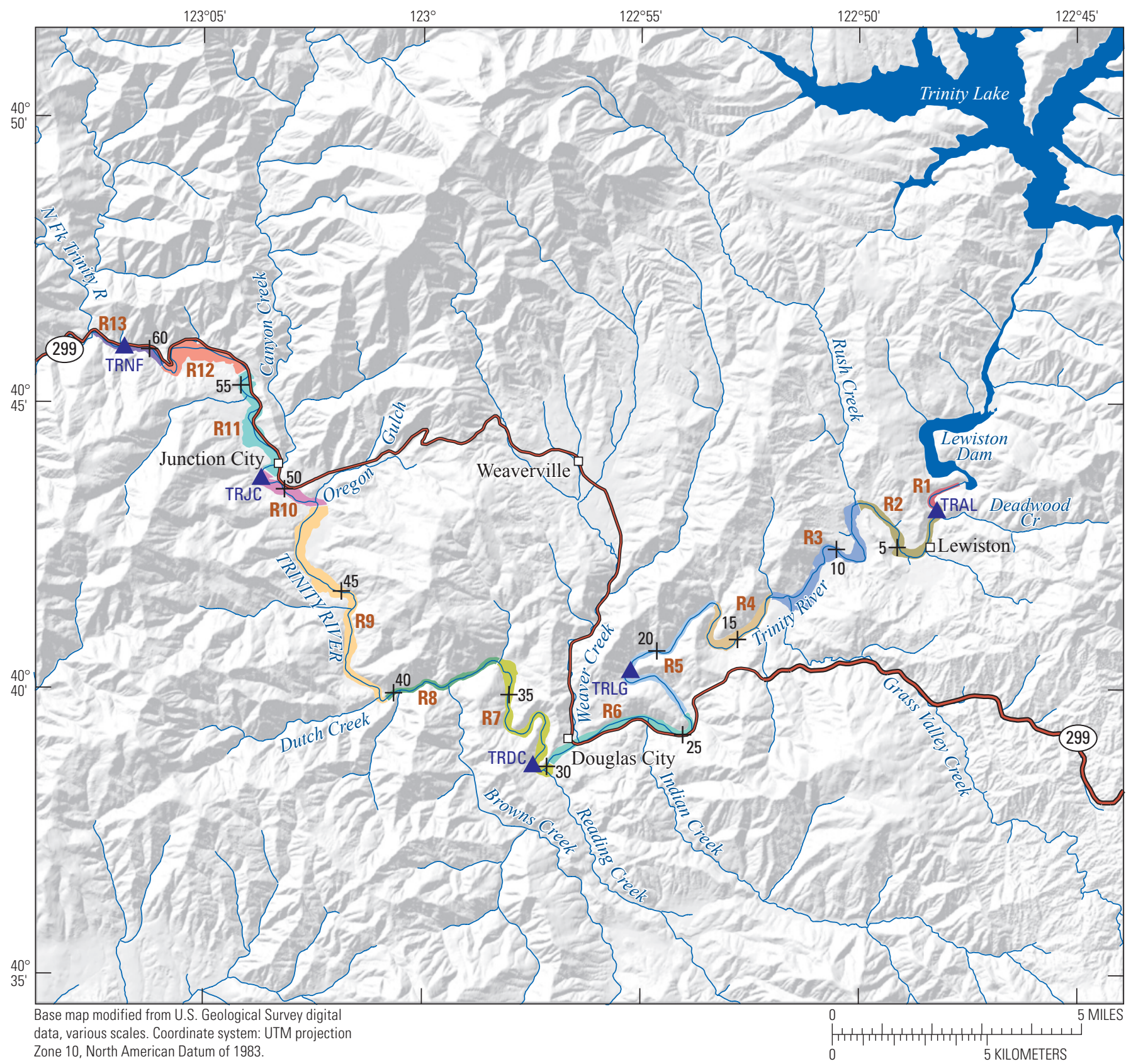

\section{EXPLANATION}

R1 Study reaches

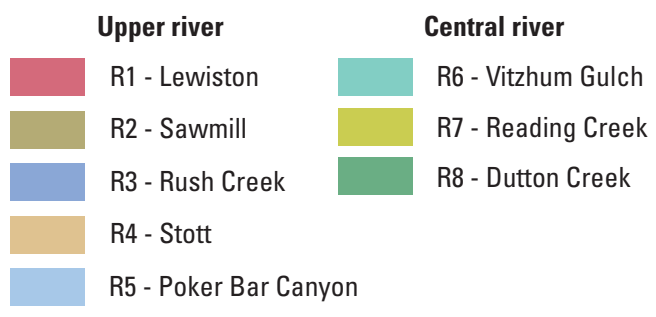

\section{Lower river}

R9 - Dutch Creek

R10 - Oregon Gulch

R11 - Canyon Creek

R12 - Lime Point

R13 - Pear Tree

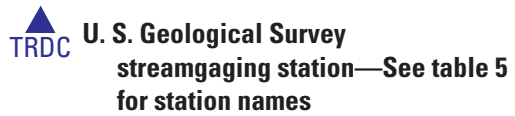

streamgaging station-See table 5

+5 Floodplain kilometer-distance downstream from Lewiston Dam

Figure 2. Study area along the Trinity River, California, extending from Lewiston Dam to the confluence of the North Fork Trinity River. 


\section{Geomorphic Mapping Geodatabase}

This report documents an ARCMAP geodatabase (v.10.0) containing geomorphic features digitized from a series of rectified orthophotography (http://dx.doi.org/10.5066/ F7TT4P04). Orthophotography was acquired during baseflow channel conditions in 1980, 1997, 2001, 2006, 2009, and 2011 and was used as the base imagery for a series of six digital geomorphic maps (table 1). Additional photography from 1960, 1965, and 1975 was used to determine the extent of pre- and post-dam geomorphic features. A map boundary was defined by an estimated water-surface extent for a flood with a 500-year recurrence interval (California Department of Water Resources, 2007). This map boundary roughly defined the valley bottom, but it was too narrow in the reach immediately downstream from Lewiston Dam; consequently, the boundary was extended by 30 -meters $(\mathrm{m})$ to accommodate all features of interest.

The geodatabase includes a feature dataset for each map date. Each feature dataset includes two feature classes: a centerline and geomorphic feature polygons. Centerlines were digitized at a 1:2,000 scale through the geographic center of the primary wetted channel as seen in the base image. Geomorphic feature polygons were constructed by using fields and domains (table 2), which enabled dynamic labeling during the digitization process and the creation of associated attribute tables. All geomorphic features larger than 30 square meters $\left(\mathrm{m}^{2}\right)$ were digitized at a scale of $1: 1,000$. The baseflow centerlines and geomorphic feature delineations were reviewed by project scientists at a scale of 1:2,000 to ensure consistency between study reaches and among study periods.

Table 1. Ortho-rectified photography and acquisition dates $(1960,1965,1975,1980,1997,2001,2006,2009,2011)$ for base imagery used to produce six geomorphic maps of the study area along the Trinity River, California, downstream from Lewiston Dam.

[Abbreviations: Aug, August; ft, feet; $\mathrm{ft}^{3} / \mathrm{s}$, cubic feet per second; Jun, June; mm/dd/yyyy, month/day/year; Oct, October; Sept, September; USGS, U.S. Geological Survey]

\begin{tabular}{cccc}
\hline Year & $\begin{array}{c}\text { Acquisition } \\
\text { dates } \\
\text { (mm/dd/yyyy) }\end{array}$ & $\begin{array}{c}\text { Rectified } \\
\text { orthophoto } \\
\text { resolution } \\
\text { (ft) }\end{array}$ & $\begin{array}{c}\text { Mean daily } \\
\text { streamflow } \\
\left(\mathbf{f t}^{\mathbf{3}} / \mathbf{s}\right)^{\mathbf{1}}\end{array}$ \\
\hline 1960 & Aug/Sept/Oct 1960 & 1.5 & 162 \\
1965 & Aug 1965 & 2 & 158 \\
1975 & Jun 1975 & 1.5 & 1,133 \\
1980 & $05 / 16 / 1980$ & 2 & 288 \\
1997 & $10 / 20 / 1997$ & 0.5 & 285 \\
2001 & $11 / 07 / 2001$ & 0.5 & 298 \\
2006 & $07 / 25 / 2006$ & 0.5 & 405 \\
2009 & $04 / 16 / 2009$ & 0.5 & 291 \\
2011 & $08 / 16 / 2011$ & 0.5 & 446 \\
\hline
\end{tabular}

${ }^{1}$ Measured at USGS gaging station 11525500 Trinity River downstream from Lewiston Dam.
Table 2. Coded values representing categorical differences among river features for the geodatabase entitled "Trinity River California Geomorphic Maps 1980-2011."

\begin{tabular}{|c|c|}
\hline $\begin{array}{l}\text { Coded } \\
\text { value }\end{array}$ & Features \\
\hline \multicolumn{2}{|r|}{ Environments } \\
\hline 1 & Main channel \\
\hline 2 & Tributary \\
\hline 3 & Terrestrial \\
\hline \multicolumn{2}{|r|}{ Terrestrial } \\
\hline 1 & Other \\
\hline 2 & Floodplain \\
\hline 3 & Island \\
\hline 4 & Post-dam topographic bench \\
\hline 5 & Surface-water feature \\
\hline 6 & Uplands \\
\hline \multicolumn{2}{|r|}{ Channel } \\
\hline 1 & Wetted channel \\
\hline 2 & Secondary water features \\
\hline 3 & Bedrock \\
\hline 4 & Bar \\
\hline 5 & Other \\
\hline \multicolumn{2}{|r|}{ Secondary water features } \\
\hline 1 & Alcove \\
\hline 2 & Wetland \\
\hline 3 & Side channel \\
\hline 4 & Split-flow channel \\
\hline \multicolumn{2}{|r|}{ Additional feature attributes } \\
\hline \multicolumn{2}{|r|}{ Bar type } \\
\hline 1 & Lateral \\
\hline 2 & Medial \\
\hline \multicolumn{2}{|r|}{ Vegetation } \\
\hline 1 & Bare to sparse \\
\hline 2 & Moderate \\
\hline 3 & Dense \\
\hline \multicolumn{2}{|r|}{ Bar stability } \\
\hline 1 & Stable \\
\hline 2 & Active \\
\hline \multicolumn{2}{|r|}{ Restoration } \\
\hline 1 & Constructed \\
\hline
\end{tabular}

\section{Mapping Protocol}

The mapping protocol developed in this study (fig. 3) includes channel features, topographically inset to riparian and upland features, which were confined by valley margins (fig. 4). Example maps (fig. 5) show the juxtaposition of upland, riparian, and channel features. 


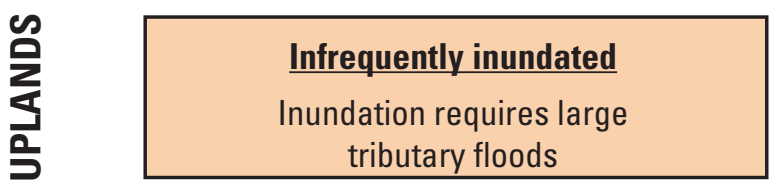

Uplands include areas underlain by soil, colluvium, alluvium, bedrock, or legacy mine tailings.

Flow threshold greater than $11,000 \mathrm{ft}^{3} / \mathrm{s}$
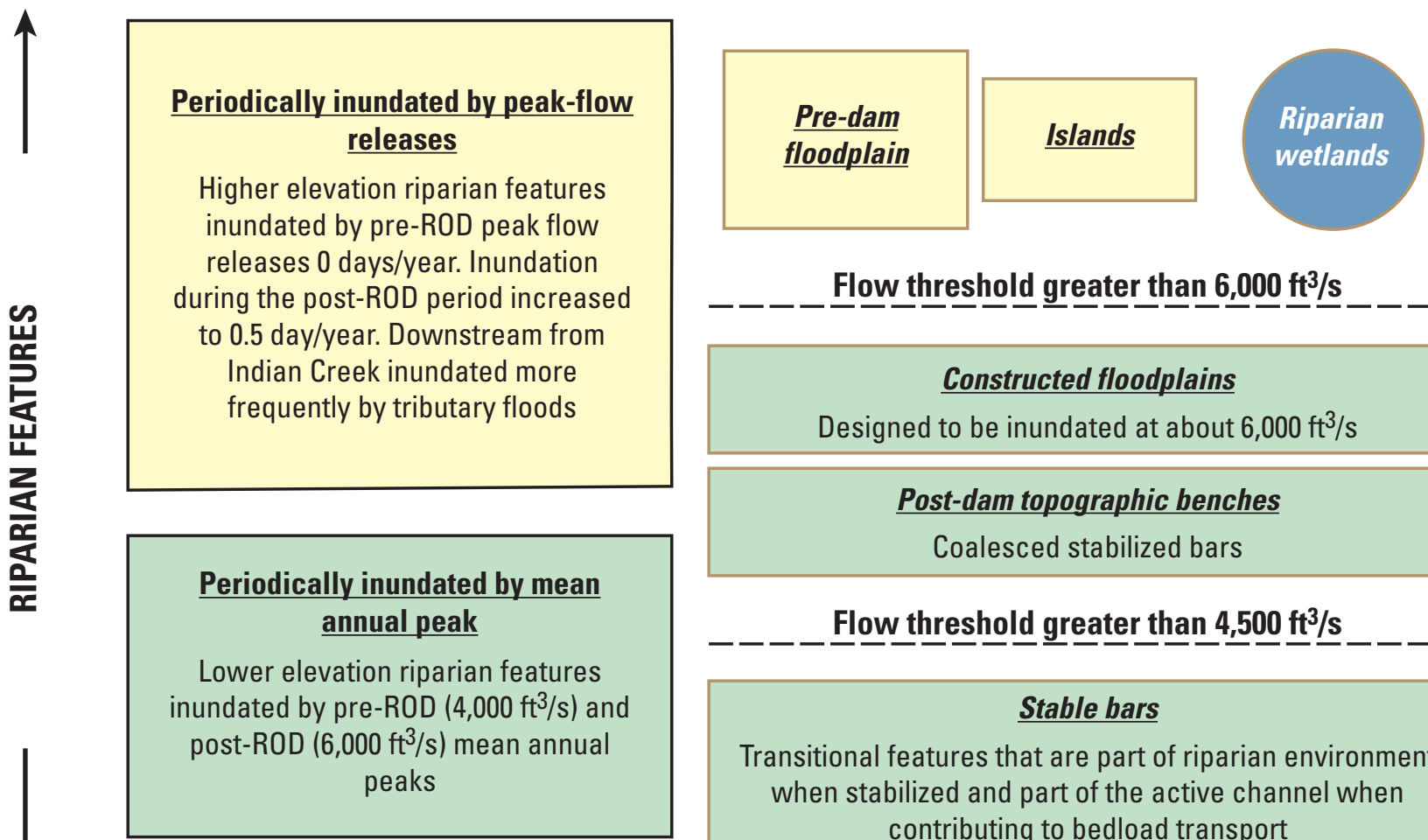

Flow threshold greater than $6,000 \mathrm{ft}^{3} / \mathrm{s}$

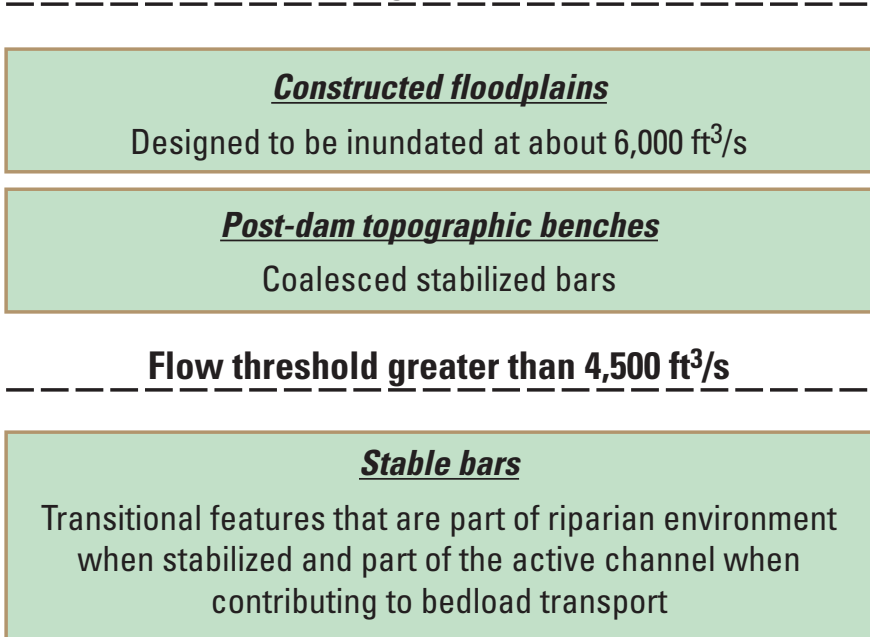

Flow threshold greater than $2,000 \mathrm{ft}^{3} / \mathrm{s}$
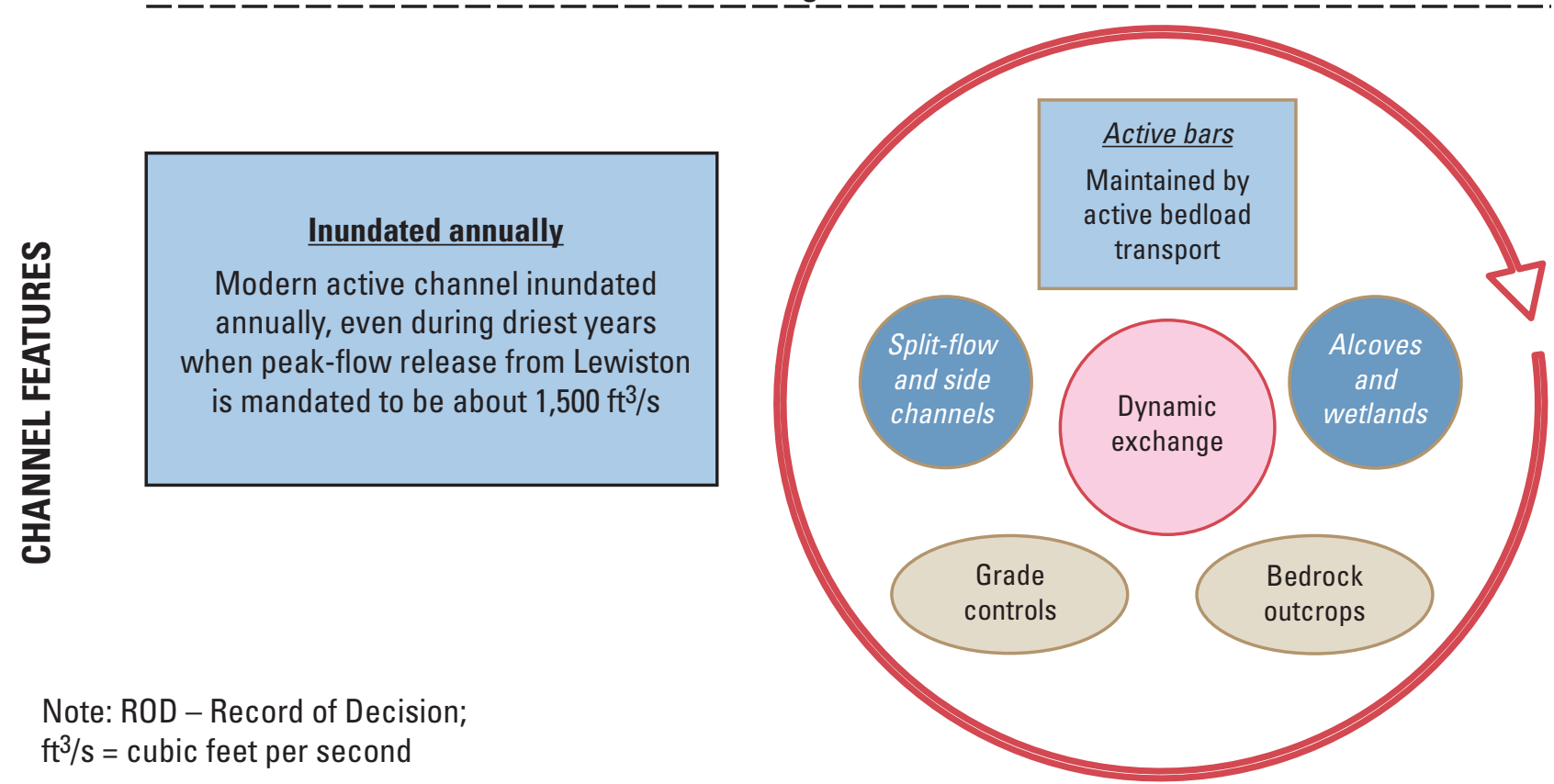

Note: ROD - Record of Decision;

$\mathrm{ft}^{3} / \mathrm{s}=$ cubic feet per second

Figure 3. Diagram showing hierarchy of geomorphic mapping features with an explanation of the size and frequency of inundation by peak-flow releases from Lewiston Dam in California. Flow thresholds were estimated at the Lewiston gage (see fig. 2 for gage location). 


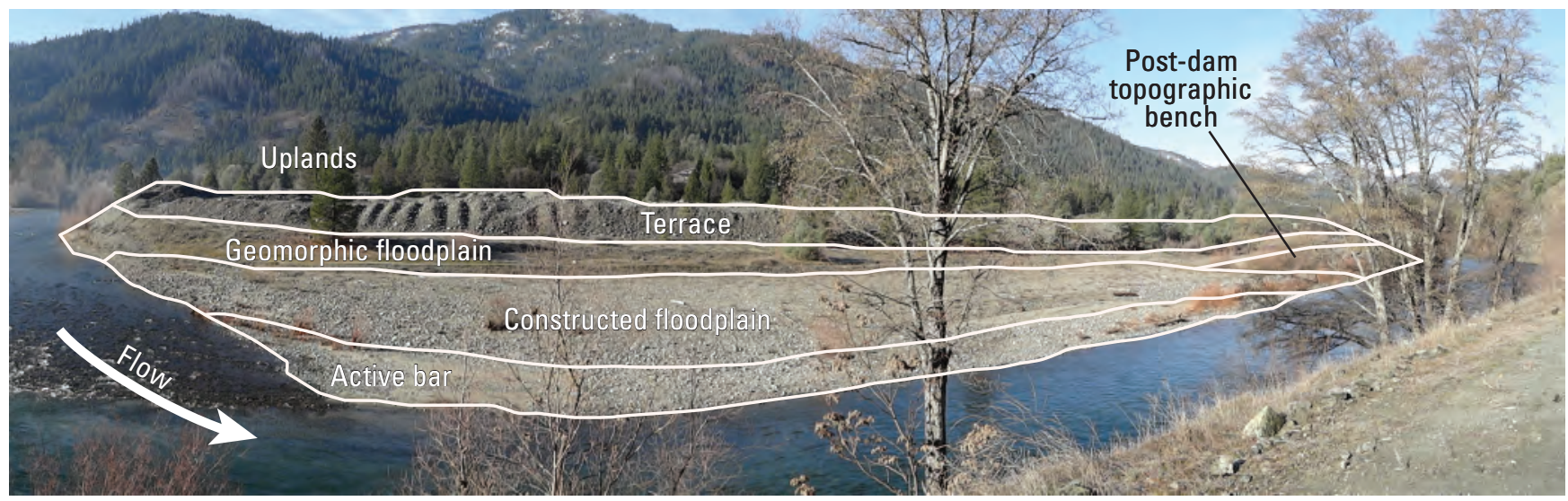

Figure 4. Example of the topographic relation among depositional and constructed features on the Trinity River, California, downstream from Lewiston Dam. Photo shows features on the left bank downstream from Canyon Creek. Photo credit: J.A. Curtis, U.S. Geological Survey.

Channel features were assigned to either mainstem or tributary environments. At tributary confluences, mainstem and tributary features were distinguished by the general trajectory of the feature compared to the mainstem and tributary channel trajectories, which were typically orthogonal to one another. Mainstem features were parallel to the mainstem channel trajectory, and tributary features were parallel to tributary channel trajectories.

Three additional categories of attributes were included in the geodatabase: (1) constructed features were labeled to enable assessment of features created or altered mechanically by in-channel gravel placement, side-channel construction, or bank rehabilitation; (2) all bar features were assigned to a vegetation density class; and, (3) a bar-stability classification was assigned by using vegetation type and density and the presence or absence of vegetation along the baseflowchannel margin as an indicator of recent scour or deposition. Assessment of sequential imagery indicated active bars typically had bare-to-sparse vegetation and a dynamic perimeter along the channel margin. In comparison, stable bars can have bare-to-dense vegetation, but generally have a stable areal extent in successive sets of base imagery. Figure 6 illustrates the relation among bars, vegetation, and the stability classification.

\section{Feature Descriptions}

The channel and terrestrial features included in the geodatabase were defined according to specific geomorphic characteristics that can vary spatially and temporally, but typify the feature. The channel environment included mainstem and tributary features, and the terrestrial environment included upland and riparian features. The activechannel margin, which represents the boundary between channel and riparian environments, shifted periodically as a consequence of the presence or absence of annual scouring flows, vegetation encroachment, and mechanical rehabilitation of channel margins during the 1980-2011 study period. 

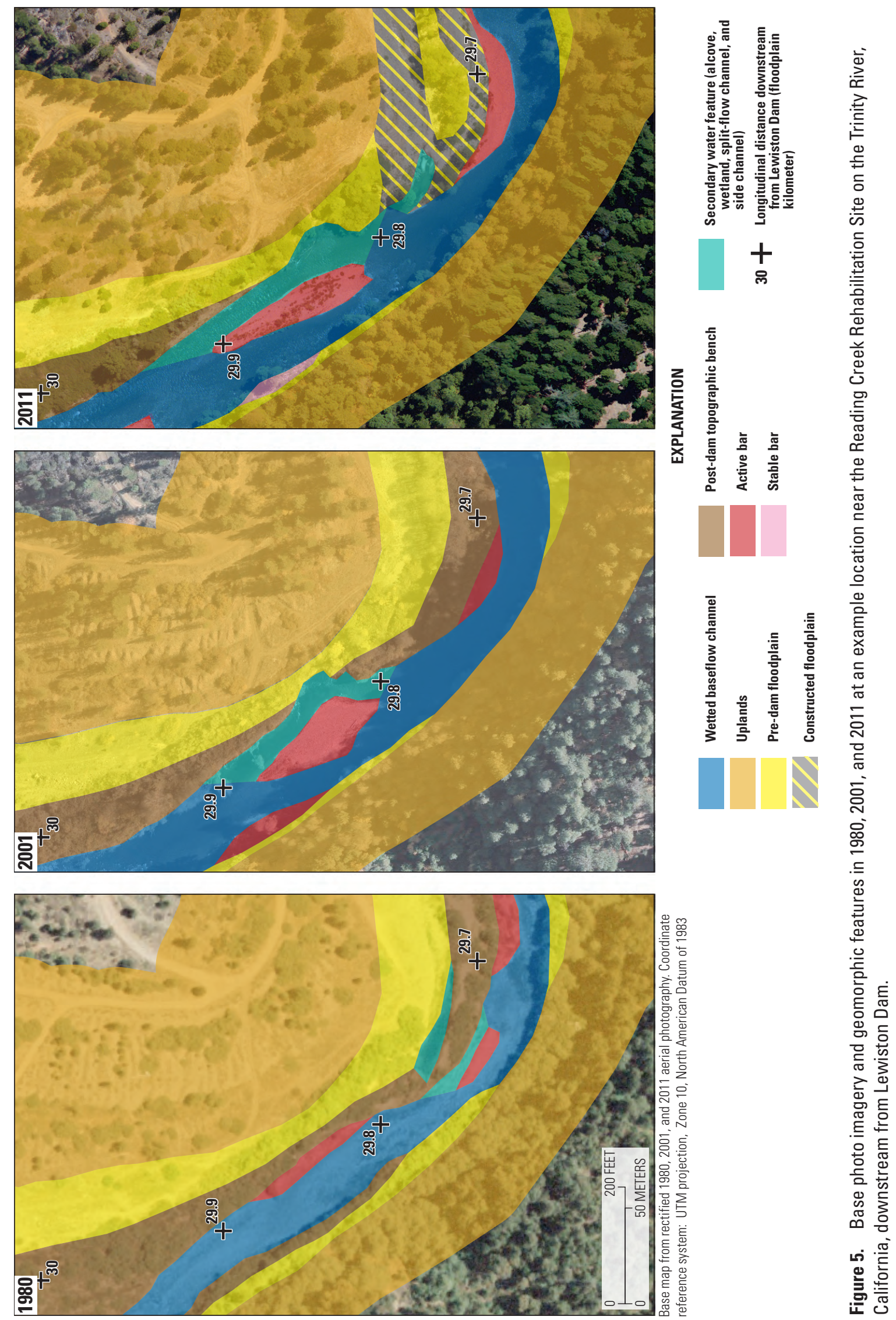

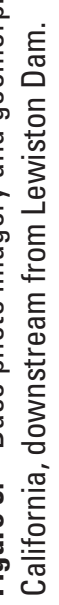



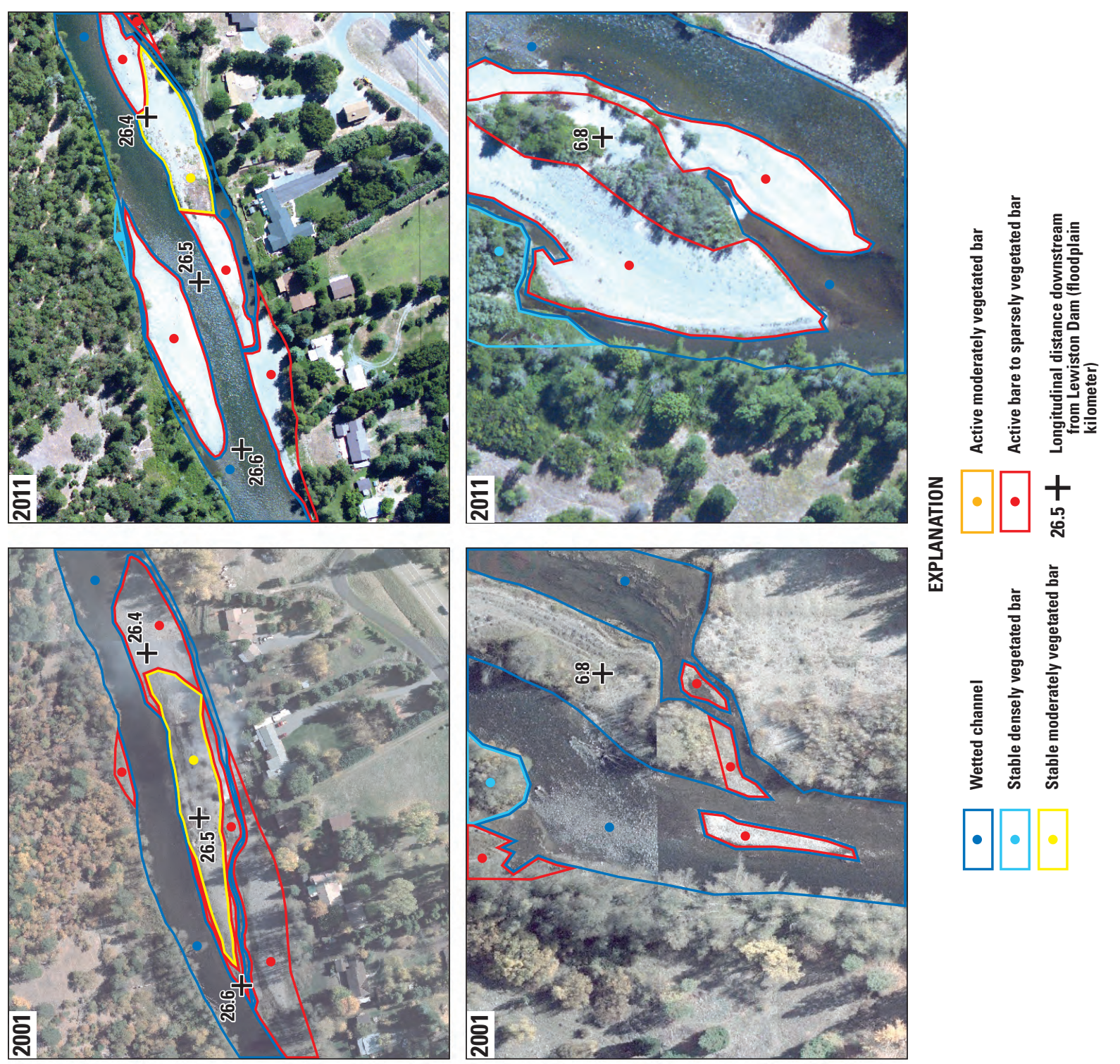

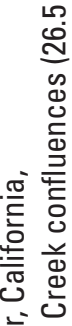

ऐं बे

ते

일

需

要

음

욛 흥

흘

엉

$\frac{0}{0}$

高

幽

$+\infty$

至

궁

들

훙 흠

용

듬

s 은

증

원.

可

焉

등

ᄃ

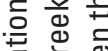

厅

要

$>$ 요

帘

प $E$

\&

응

ह్ 츠

증

중

文灾

范 돈

웅 密

응

인

$\infty$ E

0.

๒

흔 흥흥

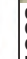

ঞ్ 


\section{Channel Features}

The baseflow-wetted channel area was defined as the wetted perimeter of the channel as seen in the base imagery. Where the channel splits, the primary channel was identified as the widest channel, and narrower channels were mapped as secondary water features and were classified as either side channels or split-flow channels. Where the wetted perimeter was obscured by vegetation or shadows, best judgment was used to delineate the boundary.

Secondary water features were defined as wetted features that do not deliver the majority of channel flow. Only areas containing water in the base imagery were mapped, even when it was apparent that additional areas could be inundated at higher flows. Secondary water features included alcoves, wetlands, side channels and split-flow channels. The relation between secondary-water features and the primary wetted channel is shown in figure 7.

1. Alcove - a secondary-water feature connected at one end to any wetted channel, including a mainstem, tributary, side, or split-flow channel.

2. Wetland - a secondary-water feature completely disconnected from any other wetted channel feature.

3. Side channels - narrow, secondary channels connected to the primary channel at the upstream and downstream ends; they are distinguished from split-flow channels by conveyance of less than 20 percent of total summer base flow and generally less than 10 percent. Flowconveyance percentages were estimated from the channel widths. Transient small-scale side channels created by scour of channel bars or by flow diversion around bedrock outcrops (less than $50 \mathrm{~m}^{2}$ ), often referred to as scour channels, were mapped as side channels and distinguished from split-flow channels by channel width and evidence of flat-water conditions.

4. Split-flow channel - secondary channels created by flow separation caused by the presence of medial bars, islands, or bedrock outcrops (greater than $50 \mathrm{~m}^{2}$ ) that change the channel morphology. Split-flow channels convey between 20 and 50 percent of the total summer baseflow. The percentage of flow conveyance was estimated from the channel widths.

Bars were defined as dynamic features created by bedload transport and were typically oriented parallel to the primary flow direction. The boundary between bars and surrounding riparian or upland features migrated through time and was delineated from observational criteria that included morphology, vegetation type and density, and physical evidence of scour or deposition.
1. Medial bar-depositional channel feature constructed and maintained by active bedload transport and surrounded by water on all sides.

2. Lateral bar - depositional channel feature constructed and maintained by active bedload transport and attached to the channel margin.

Bedrock was defined as a static, non-alluvial feature that was persistent in most or all years of the base imagery but may be buried by sediment in some years and exposed in others. Bedrock outcrops were typically darker than surrounding alluvial features and had a rough tone, jagged boundary, and lineations indicative of bedrock texture.

'Other' was defined as a category for unique channel features, including constructed features, such as hydraulic grade controls, bank-stabilization features, and historic bridge pilings. Additional details of interest are included in the 'Notes' field.

\section{Terrestrial Features}

The terrestrial environment included upland and riparian features. Under the post-dam flow regime, upland features were inundated only during extreme flow events. In comparison, riparian features were periodically inundated by flow releases from Lewiston Dam and by tributary-induced floods. The riparian environment included islands, floodplains, and wetlands.

Uplands were defined as an undifferentiated catch-all category used to delineate all areas upslope from other riparian and channel features; these areas are typically at elevations greater than $3.0 \mathrm{~m}$ above the 2009 baseflow-wetted channel (Woolpert, 2010). Uplands can include areas underlain by soil, colluvium, alluvium, bedrock or legacy mine tailings, which could not be differentiated in the base imagery. Unless altered by mechanical restoration, the areal extent of upland features typically persisted throughout the historic imagery.

Islands were defined as depositional features bounded on all sides by water and distinguished from medial bars by high-density, mature vegetation; elevations were typically greater than $1.5 \mathrm{~m}$ above the 2009 baseflow-wetted channel and had areal extents much larger than those of medial bars. Although islands existed during pre-restoration periods, many islands are constructed features created during channel rehabilitation by side-channel construction, which detached these features from adjacent channel margins.

Three floodplain types were defined in this study: a higher elevation, pre-dam floodplain; mid-elevation constructed floodplains; and lower elevation topographic benches created by the managed-flow regime. The relation among islands and floodplain types is illustrated in figure 8 . 

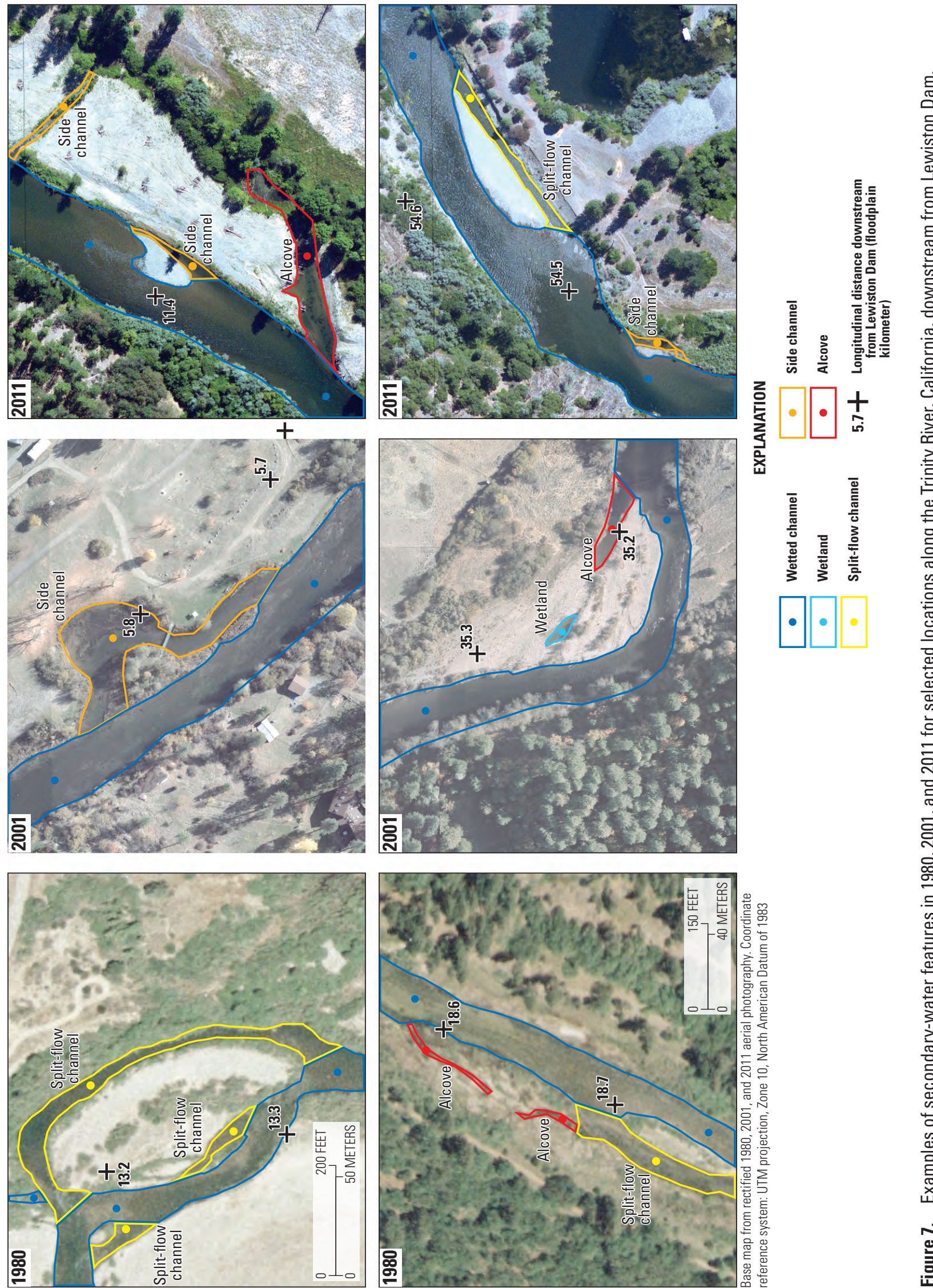

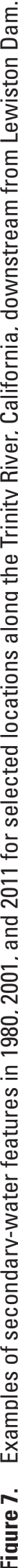



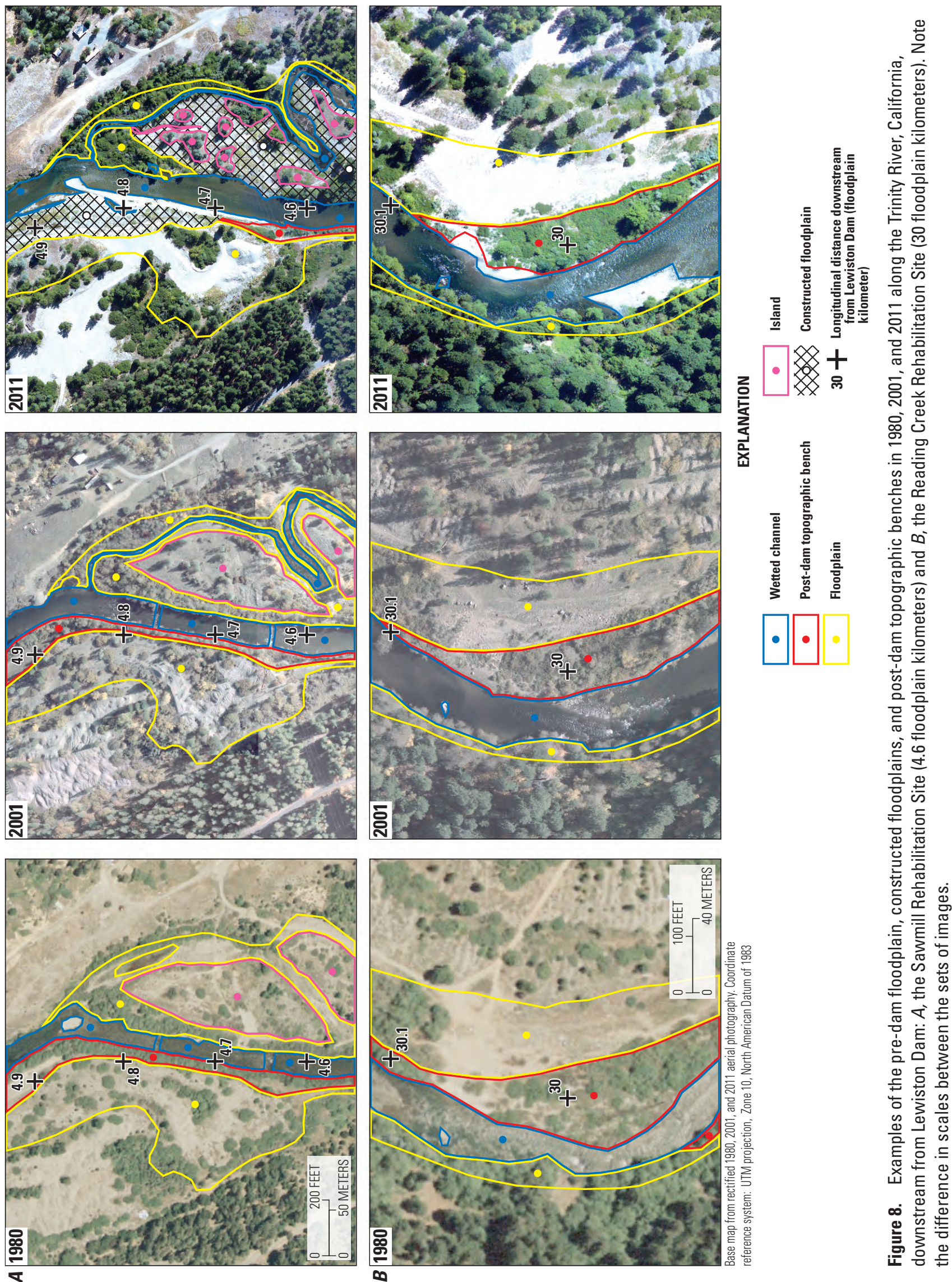

d

言离.

要 出

용

ד

ఏ غ

등

:

可

है

X

$\infty$ 离

言 
All three floodplain types typically exhibit a vegetation gradient: high-density vegetation along the active channel margin transitions to lower density vegetation as distance from the channel margin increases. The pre-dam floodplain was defined as a broad relict feature originally created and maintained by the unregulated pre-dam flow regime. The 1960 and 1965 orthophotography was used to constrain the pre-dam floodplain boundary. Lack of complete coverage for 1960 required use of the 1965 imagery for a $7-\mathrm{km}$ reach. This relatively continuous depositional feature was typically about 1.5-3.0 m above the 2009 baseflow-wetted channel. Under the post-dam flow regime, this feature was inundated periodically by flows between about 6,000 and $11,000 \mathrm{ft}^{3} / \mathrm{s}$ (Curtis and others, 2015).

Constructed floodplains were defined as discontinuous restoration features created by mechanical vegetation removal, re-contouring of riparian areas adjacent to channel margins, and surface lowering as part of the U.S. Fish and Wildlife Service (USFWS) bank rehabilitation program in the early 1990s and the TRRP bank-rehabilitation program since 2005. The smaller scale USFWS features are also referred to as feathered-edge features. The larger scale managed floodplains constructed by the TRRP were designed to be inundated by the post-ROD mean annual peak flow, estimated to be about $6,000 \mathrm{ft}^{3} / \mathrm{s}$ at the Lewiston gage. These constructed features are typically about $1.0-1.5 \mathrm{~m}$ above the 2009 baseflow-wetted channel.

Post-dam topographic benches were defined as depositional features composed of formerly active bars, which were stabilized prior to 1975 as a result of declines in scouring flows and an associated increase in vegetation encroachment. The post- 1975 stable bars subsequently coalesced into low-elevation riparian features throughout the $65-\mathrm{km}$ study reach. Portions of these features can be elevated as a result of vegetation-facilitated deposition and the development of a riparian berm along the channel margin. Many of these berms and benches were lowered and converted into constructed features as part of the USFWS and TRRP channelrehabilitation projects. These low-elevation floodplain features are typically $0.5-1.5 \mathrm{~m}$ above the 2009 baseflow-wetted channel. Under the post-ROD flow regime, these features were inundated more frequently than constructed floodplains by flows between about 4,500 and $6,000 \mathrm{ft}^{3} / \mathrm{s}$.

Surface-water features in the terrestrial environment were limited to riparian wetlands, which were defined as disconnected aquatic features outside the active-channel boundary. Only areas containing water in the base imagery were mapped, even when it was apparent that additional areas were inundated seasonally.

'Other' was defined as a category for unique riparian features including constructed features, such as borrow pits and gravel-recruitment piles. Additional details of interest are included in the 'Notes' field.

\section{Transitional Bars and Constructed Features}

The boundaries between depositional features are often topographically indistinct, and in this study, the active-channel margin, which represents the boundary between the channel and riparian environments, shifted throughout the study period. Laterally accreted sediment adjacent to the channel margin that has been stabilized by vegetation encroachment could be mapped as a stable bar feature or as part of the adjacent riparian feature. We chose to retain the original bar designation for features that transitioned from active to stable bars during the study period and assigned a stability index such that lower elevation, densely vegetated bars could be distinguished from older, topographically higher, denselyvegetated floodplain features. Geodatabase users may decide how to integrate stable well-vegetated bars into a geomorphic framework that suits their purpose. For example, stable bars could be combined with the post-dam topographic bench features to define a post-dam managed-floodplain. Retaining the original bar classification allowed for subsequent bar formation and stabilization to be followed through time and also indicates to the database user that this feature was formerly part of the post-dam active channel. Likewise, if terrestrial features were inundated and altered by a high-flow event, we continued to map the area as a terrestrial feature, even when sediment was deposited or surface scour occurred.

We chose 1975 to delineate a bar-stability threshold. In 1974, the largest post-dam flow release scoured channelmargin vegetation and deposited sediment, causing incipient bar formation. If a bar was scoured and mobilized by the 1974 event, or deposited after 1975 and stabilized by vegetation in subsequent years (1980-2011), it was mapped as a bar in all years, and an appropriate bar-stability classification was applied. The density of bar vegetation was defined for all bar features according to relative cover classes. Less than 10 percent vegetation cover was classified as bare to sparse cover; from 10 to 40 percent vegetation cover was classified as moderate cover; and greater than 40 percent vegetation cover was classified as dense cover.

Observations of sediment scour or deposition and the age, type, density, and spatial distribution of vegetation were used to delineate the active-channel boundary, and these observational criteria were also used to define relative stability classes. No physical evidence of scour, mobilization, or deposition compared to the previous imagery was classified as stable. More specifically, the channel margin can have bare-to-dense vegetation, but must have a stable areal extent when compared to the previous imagery. If there was obvious physical evidence of scour, mobilization, or deposition, and the baseflow-channel margin and the bar-surface area were bare-to-sparsely vegetated, when compared to previous imagery, then the bar is classified as active. 
Constructed features were defined as features explicitly created by mechanical restoration and were designated in the geodatabase under the restoration field by the label "constructed." Constructed features included any feature created by in-channel gravel placement; side-channel construction; or bank rehabilitation, including riparian berm removal and re-contouring of channel margins. The constructed classification was retained in subsequent periods, indicating to the database user when the feature was constructed.

\section{Centerlines}

Centerlines for each base imagery date were digitized at 1:2,000 through the geographic center of the primary baseflow-wetted channel boundary, as seen in the base image. Where multiple channels existed, such as side channels and split-flow channels, the centerline bisected the primary channel. Centerlines may bisect small active bars (less than $30 \mathrm{~m}^{2}$ ) and bedrock outcrops (less than $50 \mathrm{~m}^{2}$ ), but always circumvent larger features or stable, well-vegetated bars and islands to follow the primary baseflow channel.

\section{Uncertainty Analysis}

Errors occur at all stages of data transcription when real-world data are transferred to digital formats (Mount and Louis, 2005). Errors associated with digitized data generally include operational errors, differences in the exposure of channel units due to variable streamflows during sequential photo acquisition, and digitizing errors due to rectification of the base imagery or feature obscurity related to vegetation or shadows.

Operational errors during the digitizing process were addressed by a rigorous quality-assurance/quality-control (QA/QC) program and were assumed to be negligible. All linework was reviewed and edited by the lead project scientist at 1:2,000 to ensure consistency between reaches and among study periods. The mapping protocol was field checked during the summer of 2012. Field observations of vegetation transitions, breaks in slope, and evidence of scour or deposition were used to verify the perimeter of individual geomorphic features and associated attributes delineated from the 2011 imagery.

Errors related to variable streamflow were estimated from the stage-discharge relations of the five mainstem gaging stations in the study area (fig. 2). Differences in baseflow during acquisition of the 1980, 1997, 2001, and 2009 imagery were relatively small and flows ranged from 285 to $298 \mathrm{ft}^{3} / \mathrm{s}$, but flows were much higher in 2006 and 2011 (table 1).

Analysis of the stage-discharge relations indicated an average difference in water depths of about $0.1 \mathrm{~m}$ during acquisition of the 2006 and 2011 imagery. If the margins of the geomorphic features have slope angles at or greater than the angle of repose for unconsolidated sediments (about 45 degrees), a reasonable assumption for gravel bars and cutbanks, the horizontal error due to variable streamflow would be equal to or less than the estimated differences in stage, which were relatively small $(0.1 \mathrm{~m})$.

Uncertainty associated with rectified imagery is typically quantified by using the root mean square error (RMSE), even though recent studies have shown it is a poor indicator of the overall horizontal accuracy (Hughes and others, 2006). Available reports indicate the RMSE for the 2009 and 2011 imagery (Woolpert, 2010; Watershed Sciences, 2011) to be 0.4 and $0.2 \mathrm{~m}$, respectively. We used metadata associated with the 2001 and 2006 datasets to determine that this imagery met national accuracy standards (Federal Geographic Data Committee, 1998). Using this information, we estimated the RMSE for the 2001 and 2006 imagery to be approximately $1.5 \mathrm{~m}$ on the basis of pixel resolution. Registration and rectification errors associated with the 1980 and 1997 imagery were greater because of a lack of camera calibration data, which had to be estimated (written commun., Eric Peterson, Bureau of Reclamation, May 1, 2012). The resolution of the 1997 imagery was the same as the 2001 imagery; therefore, we inferred the RMSE to be the same (about $1.5 \mathrm{~m}$ ). The pixel resolution of the 1980 imagery was lower $(0.6 \mathrm{~m})$, and on the basis of national accuracy standards (Federal Geographic Data Committee, 1998), we inferred the RMSE for the 1980 imagery, at $9.8 \mathrm{~m}$, was much higher than that for imagery from other years.

Digitizing errors were quantified by assessing the accuracy and precision of the digitized linework. Vegetation and shadows obscured portions of geomorphic features in all of the ortho-photography, but were most problematic for delineating channel features. Shadows were more problematic for images collected during the fall of 1997 and 2001, although some features were better exposed because of the lack of leaf cover. A line width of 0.5 millimeters $(\mathrm{mm})$ represents a ground distance of $0.5 \mathrm{~m}$ at the $1: 1000$ scale. We buffered our linework by $0.5 \mathrm{~m}$ and determined that features are well represented at 1:1,000 with line widths of $0.5 \mathrm{~mm}$. Linework precision was estimated by comparing repeat linework along jagged boundaries (bedrock), smooth boundaries (bars), and areas with dense canopy cover or shadows (meanders). Repeat linework measurements indicated that jagged boundaries had a precision of $1.0 \mathrm{~m}$, smooth boundaries had a greater precision at $0.85 \mathrm{~m}$, and areas obscured by canopy and shadows had the least precision at $2.0 \mathrm{~m}$. Application of these precision estimates, respectively, equate to 10 percent, 7 percent, and 13 percent error for a 30-m channel width, which is representative of channel widths within the study reach, or an average error of 10 percent.

Application of linework precision to estimate an overall digitizing error associated with the geodatabase features is scale and location dependent. Features that occupy a smaller 
spatial area or are obscured by vegetation or shadows have greater uncertainty due to digitizing errors. When the lowest linework precision $(2 \mathrm{~m})$ was applied to an equi-dimensional feature with an areal extent of $100 \mathrm{~m}^{2}$ and a perimeter of $40 \mathrm{~m}$, the estimated uncertainty in the digitized area was 10 percent. In comparison, the mean area estimated for active bars digitized from the 2011 imagery was $520 \mathrm{~m}^{2}$, and the mean perimeter was $130 \mathrm{~m}$. Application of the lowest linework precision $(2 \mathrm{~m})$ to an equi-dimensional feature with a perimeter of $130 \mathrm{~m}$ resulted in an estimated uncertainty of 3 percent.

Because operational errors and variable-discharge errors were inferred to be negligible, uncertainty associated with the digitized data was represented best by digitizing errors related to a feature being obscured by vegetation or shadows. Ultimately, we inferred a relatively conservative estimate for digitizing errors of 10 percent, which was comparable to recent studies (Juracek, 2000; Micheli and others, 2004; Swanson and others, 2011).

\section{References Cited}

California Department of Water Resources Northern District, 2007, Trinity River Hydraulic Flow Study North Fork Trinity to Lewiston Dam, Sacramento, California, 85 p. http://odp.trrp.net/FileDatabase/Documents/DWR HydraulicFlowStudyReport_forTRRP_Final_2007071.pdf.

Curtis, J.A., and Guerrero, T.M., 2015, Database of Geomorphic Features, Trinity River, California, 19802011: U.S. Geological Survey Data Release http://dx.doi. org/10.5066/F7TT4P04.

Curtis, J.A., Wright, S.A., Minear, J.T., and Flint, L.E., 2015, Assessing geomorphic change along the Trinity River downstream from Lewiston Dam, California, 1980 to 2011: U.S. Geological Survey Scientific Investigation Report 2015-5046, 69 p.

Federal Geographic Data Committee, 1998, Geospatial Positioning Accuracy Standards Part 3: National Standard for Spatial Data Accuracy, FGDC-STD-007.3-1998 (revised June 1998), Federal Geographic Data Committee, Washington, D.C., 78 p. https://www.fgdc.gov/standards/ projects/FGDC-standards-projects/accuracy/part3/chapter3.

Gaeuman, D., 2009, Water year 2010 implementation monitoring report, Technical Report Series, TR-TRRP-2011-1: U.S. Bureau of Reclamation, Trinity River Restoration Program, Weaverville, Calif., 58 p. http://odp.trrp.net/FileDatabase/Documents/Gaeuman\%20 2011\%20Water\%20year\%202010\%20implementation $\% 20$ monitoring1.pdf.
Gallagher, S.P., 1995, Evaluation of the feathered edge restoration projects on the Trinity River: fish use and physical habitat: U.S. Fish and Wildlife Service, Division of Ecological Services, Instream Flow Branch, Sacramento, Calif., 28 p. http://books.google.com/books/ about/Evaluation_of_the_Feathered_Edge_Restora. $\mathrm{html}$ ?id=mlglPwAACAAJ.

Hoopa Valley Tribe, McBain and Trush, Inc., and Northern Hydrology and Engineering, 2011a, Channel rehabilitation design guidelines for the mainstem Trinity River: Hoopa, Calif., Trinity River Restoration Program, 338 p. http://odp. trrp.net/FileDatabase/Documents/Trinity\%20River\%20 Channel\%20Design\%20Guide\%201-21-11\%20reduced2. pdf.

Hoopa Valley Tribe, U.S. Fish and Wildlife Service, and Yurok Tribe, 2011b, Integrated habitat assessment of the Upper Trinity River, 2009: Draft Report: Prepared for the Trinity River Restoration Program, Hoopa, Calif., 336 p.

Hughes, M.L., McDowell, P.F., and Marcus, W.A., 2006, Accuracy assessment of georectified aerial photographsImplications for measuring lateral channel movement in GIS: Geomorphology, v. 74, p. 1-16. http://dx.doi. org/10.1016/j.geomorph.2005.07.001.

Irwin, W.P., 1994, Geologic map of the Klamath Mountains, California: U.S. Geological Survey Miscellaneous Investigations Series Map I-2148, scale 1:500,000, 2 sheets. http://ngmdb.usgs.gov/Prodesc/proddesc_10149.htm.

Irwin, W.P., 1966, Geology of the Klamath Mountains province: Geology of northern California: California Division of Mines and Geology Bulletin v. 190, p. 17-61.

Juracek, K.E., 2000, Channel stability downstream from a dam assessed using aerial photographs and stream-gage information: Journal of the American Water Resources Association, v. 36, no. 3, p. 333-345. DOI: 10.1111/j.17521688.2000.tb04293.x.

May, C.L., Pryor, B., Lisle, T.E., and Lang, M., 2009, Coupling hydrodynamic modeling and empirical measures of bed mobility to predict the risk of scour and fill of salmon redds in a large regulated river: Water Resources Research, v. 45, 22 p., W05402. doi:10.1029/2007WR006498.

McBain and Trush, Inc., 1997, Trinity River maintenance flow study_Final Report: Arcata, Calif., Hoopa Valley Tribe, McBain and Trush, Inc., 482 p. http://odp.trrp.net/ FileDatabase/Documents/Trinity\%20Maintenance $\% 20$ Flow\%20Study\%20-\%20November\%201997.pdf. 
Micheli, E.R., Kirchner, J.W., and Larsen, E.W., 2004, Quantifying the effect of riparian forest versus agricultural vegetation on river meander migration rates, Central Sacramento River, California, U.S.A.: River Research and Applications, v. 20, p. 537-548. doi: 10.1002/rra.756.

Mount, N.J., and Louis, J., 2005, Estimation and propagation of error in the measurement of river channel movement from aerial imagery: Earth Surface Processes and Landforms, v. 30, no. 5, p. 635-643. doi: 10.1002/esp.1172.

Swanson, B.J., Meyer, G.A., and Coonrod, J.E, 2011, Historical channel narrowing along the Rio Grande near Albuquerque, New Mexico in response to peak discharge reductions and engineering: magnitude and uncertainty of change from air photo measurements: Earth Surface Processes and Landforms, v. 36, p. 885-900. doi: 10.1002/ esp.2119.

Trinity River Restoration Program, 2005, Conceptual models and hypotheses for the Trinity River Restoration Program, Draft Final Report Weaverville, Calif., Trinity River Restoration Program, 132 p. http:/odp.trrp.net/ FileDatabase/Documents/Conceptual\%20Models $\% 20$ and\%20Hypotheses\%20for\%20the\%20TRRP_FINAL1.pdf.

Trinity River Restoration Program and ESSA Technologies Ltd., 2009, Integrated assessment plan, Version 1.0September 22, 2009: Weaverville, Calif., Trinity River Restoration Program, 286 p. http:/odp.trrp.net/ FileDatabase/Documents/IAP_1.01.pdf.

U.S. Department of the Interior, 2000, Record of Decision: Trinity River mainstem fishery restoration final environmental impact statement/environmental impact Report, 43 p. http://odp.trrp.net/FileDatabase/Documents/ Trinity\%20River\%20Record\%20of\%20Decision\%2012-1900.pdf.
U.S. Fish and Wildlife Service, 1980, Environmental impact statement on the management of river flows to mitigate the loss of the Anadromous Fishery of the Trinity River, Calif., Volume I: Sacramento, California. 229 p. http://odp. trrp.net/FileDatabase/Documents/Enviro\%20Impact\%20 Statement\%20Vol.\%201\%201980b1.pdf.

U.S. Fish and Wildlife Service, and Hoopa Valley Tribe, 1999, Trinity River flow evaluation final report: Arcata, Calif., and Hoopa, Calif., U.S. Fish and Wildlife Service, Arcata Fish and Wildlife Office, 310 p. http://odp.trrp.net/FileDatabase/ Documents/USFWS\%20HVT\%201999\%20(June\%20 FINAL\%20-\%20locked)\%20Trinity\%20River\%20 Flow\%20Evaluation\%20Final\%20Report1.pdf.

Watershed Sciences, 2011,True-color orthophotographs, Trinity River, California, October 20, 2011: Trinity River Restoration Program, 12 p. http://odp.trrp.net/FileDatabase/ Documents/Trinity_Orthophoto_Report_20111.pdf.

Woolpert, Inc., 2010, Trinity River bathymetry, airborne laser data and photogrammetric DTM merging, verification and certification: Trinity River Restoration Program, U.S. Bureau of Reclamation Task Order R10PD40022, 41 p. http://odp.trrp.net/FileDatabase/Documents/TRRP_2009 DTM\&ORTHO1.pdf. 

Publishing support provided by the U.S. Geological Survey

Science Publishing Network, Sacramento and Tacoma Publishing Service Centers

For more information concerning the research in this report, contact the

Director, California Water Science Center

U.S. Geological Survey

$6000 \mathrm{~J}$ Street, Placer Hall

Sacramento, California 95819

http://ca.water.usgs.gov 
